\title{
Pengaruh Mesoscale Convective System terhadap Hujan Ekstrem Pesisir Barat Sumatra
}

\section{Achmad Fahruddin Rais, Rezky Yunita, dan Tri Setyo Hananto}

Badan Meteorologi Klimatologi dan Geofisika (BMKG), Kemayoran, Jakarta, Indonesia

* Email koresponden: achmad.rais@bmkg.go.id

Direvisi: 2020-10-14. Diterima: 2020-12-30

(C)2021 Fakultas Geografi UGM dan Ikatan Geograf Indonesia (IGI)

\begin{abstract}
Abstrak. Tulisan ini merupakan studi awal yang membuktikan pengaruh Mesoscale Convective System (MCS) terhadap curah hujan (CH) ekstrem di pesisir barat Sumatra dengan menggunakan citra rapidscan 10 menit Himawari-8 kanal IR1. Untuk mendapatkan data yang berkualitas, penulis melakukan koreksi data $\mathrm{CH}$ penakar Hellman terhadap data standar CH di Moelaboh (MLH), Sibolga (SBG), Teluk Bayur (TBR) dan Bengkulu (BKL) serta koreksi paralaks data

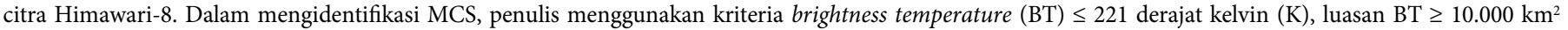
dan durasi $\geq 3$ jam. Hasil penelitian mengindikasikan bahwa $\mathrm{CH}$ ekstrem bersamaan dengan keberadaaan $\mathrm{MCS}$ yang membuktikan bahwa $\mathrm{CH}$ ekstrem diakibatkan oleh MCS di MLB, SBG, TBR dan BKL. MCS tersebut sangat dipengaruhi oleh kemunculan Westerly Wind Burst (WWB) yang terhalangi oleh Bukit Barisan untuk kasus CH ekstrem di SBG dan TBR atau berinteraksi dengan angin pasat tenggara dari Samudra Hindia sebelah barat daya Sumatra untuk kasus $\mathrm{CH}$ ekstrem di BKL. Untuk kaus CH ekstrem di MLB, MCS terbentuk akibat interaksi angin pasat di Samudra Hindia sebelah barat Sumatra dan aliran siklonik sebelah barat MLB.
\end{abstract}

Kata kunci: curah hujan ekstrem, mesoscale convective system, citra rapidscan IR

Abstract. This paper was a preliminary study that proved the impact of the mesoscale convective system (MCS) on extreme rainfall on the west coast of Sumatra using rapid scan imagery of 10 minutes Himawari-8 channel IR1. To get qualified data, we conducted the correction of rainfall data of Hellman gauge to the rainfall standard data in Moelaboh (MLH), Sibolga (SBG), Teluk Bayur (TBR), and Bengkulu (BKL) and the parallax correction to Himawari-8 imagery data. To identify $M C S$, we used brightness temperature $(B T) \leq 221 \mathrm{~K}, B T$ area $\geq 10.000 \mathrm{~km}^{2}$ and duration $\geq 3$ hours as the criteria. The results indicated that extreme rainfall occured simultaneously with MCS proved that the extreme rainfall caused by MCS in MLB, SBG, TBR, and BKL. The MCS was greatly influenced by the appearance of westerly wind burst (WWB) which was blocked by Bukit Barisan for extreme rainfall cases in SBG and TBR or interacted with the southeast trade winds of the Indian Ocean in the southwest of Sumatra for extreme rainfall case in BKL. For extreme rainfall case in MLB, MCS was formed due to the interaction of trade winds of the Indian Ocean in the west of Sumatra and cyclonic flow in the west of MLB.

Keywords: extreme rainfall, mesoscale convective system, rapid scan IR imagery

\section{PENDAHULUAN}

Dalam penelitian Putri dkk. (2017) dan Trismidianto (2018), pesisir barat Sumatra adalah salah satu area dimana mesoscale convective system (MCS) banyak terjadi. Tipikal MCS tersebut terkonsentrasi pada malam hari terutama di periode Desember-Januari-Februari (DJF) dan Maret-AprilMei (MAM) yang menyerupai variasi curah hujan $(\mathrm{CH})$ diurnal di pesisir barat Sumatra seperti dalam penelitian Mori dkk. (2004). MCS dapat didefinisikan sebagai kumpulan awan cumulonimbus (Cb) menjadi satu entitas disertai presipitasi yang mencakup skala horizontal ribuan kilometer (Houze, 2018). Oleh karena itu, banyak penelitian telah mengaitkan MCS di Indonesia dengan peningkatan $\mathrm{CH}$. Ismanto (2011) menyatakan bahwa MCS mampu meningkatkan $\mathrm{CH}$ sebesar $0.05-0.35 \mathrm{~mm} / \mathrm{jam}$ di sebagian Sumatra dalam penelitiannya. Peningkatan $\mathrm{CH} 14-18 \%$ di pesisir barat Sumatra juga ditemukan oleh Trismidianto dkk. (2017). Dengan mempergunakan produk 2BGEOPROF, Putri dkk. (2017) berhasil membuktikan bahwa terdapat partikel es presipitasi pada klaster MCS di Indonesia. Dalam penelitian Nuryanto dkk. (2019), MCS juga berperan aktif terhadap $\mathrm{CH}$ extreme yang menyebabkan banjir di Jakarta pada 15-18 Januari 2013.
Menurut Supriyadi dkk. (2017), treshold CH ekstrem berdasarkan nilai persentil 95\% tertinggi berada di pesisir barat Sumatra. Treshold tersebut juga menandakan bahwa frekuensi paling besar terjadi di pesisir barat Sumatra dengan jumlah $\mathrm{CH}$ yang sama. Oleh karena itu, $\mathrm{CH}$ di pesisir barat Sumatra sangat menarik untuk dikaji.

Penelitian MCS berbasis citra satelit geostasioner di Indonesia secara umum telah banyak dilakukan. Beberapa penelitian terbaru seperti penelitian Trismidianto (2018), Norman dan Trilaksono (2019) serta Septiadi dan Nugraha (2020) yang mengkaji MCS hanya menggunakan citra satelit IR setiap jam atau menit ke-60. Sedangkan satelit Himawari8, yang aktif mulai tahun 2014, menghasilkan brightness temperature (BT) setiap 10 menit. Citra BT setiap 10 menit sangat diperlukan untuk merepresentasikan pengaruh MCS terhadap $\mathrm{CH}$ yang merupakan nilai akumulasi selama 1 jam. Adapun fokus tulisan ini adalah menganalisis pengaruh MCS terhadap $\mathrm{CH}$ ekstrem di pesisir barat Sumatra.

\section{METODE PENELITIAN}

Data $\mathrm{CH}$ yang dianalisa adalah empat kasus $\mathrm{CH}$ ekstrem di Moelaboh (MLB), Sibolga (SBG), Teluk Bayur (TBR) dan 
Bengkulu (BKL) pada tanggal 15 Oktober, 19 Februari, 14 Februari dan 10 November di tahun 2018 (Gambar 1). Pemilihan 4 kasus tersebut karena $\mathrm{CH} 4$ kasus itu melebihi batas ambang ekstrem dalam skala setiap jam. Batas ambang diperoleh dari penurunan skala akumulasi $\mathrm{CH} 24$ jam (CH24) operasional BMKG dengan nilai $150 \mathrm{~mm} / 24 \mathrm{jam}$ ( BMKG, 2020) menjadi skala akumulasi $\mathrm{CH}$ setiap jam ( $\mathrm{t}=1$ ) berdasarkan rumus Mononobe (Mori, 2003) seperti disajikan dalam Persamaan (1).

$C H=\frac{C H 24}{24}\left(\frac{24}{t}\right)^{2 / 3}=\frac{150}{24}\left(\frac{24}{1}\right)^{2 / 3}=52.002$ (Mori, 2003)

$\mathrm{CH}$ dalam mm/jam. Pembuktian $\mathrm{CH} 4$ kasus tersebut melebihi batas ambang ekstrem digambarkan dengan Gambar 3a.

Data yang digunakan adalah data $\mathrm{CH}$ setiap jam. Data $\mathrm{CH}$ dikoreksi $\left(\mathrm{CH}^{*}\right)$ melalui perkalian dengan indeks dari perbandingan antara $\mathrm{CH}$ akumulasi 24 jam penakar Hellman (CH24) dengan $\mathrm{CH}$ akumulasi 24 jam alat standar tipe OBS $\left(\mathrm{CH}_{s} 24\right)$ seperti disajikan dalam Persamaan (2).

$\mathrm{CH}^{*}=\mathrm{CH} \frac{\mathrm{CHg}_{\mathrm{g}} \mathrm{Z4}}{\mathrm{CH} 24} \quad(\mathrm{BMKG}, 2016)$

Selain itu, citra satelit kanal infrared (IR) rapidscan 10 menit satelit Himawari-8 juga dikoreksi dengan menggunakan teknik koreksi paralaks berbasis sifat elips bumi (R) dan koreksi akibat posisi satelit ( $\mathrm{X}_{\text {corr }}, \mathrm{Y}_{\text {corr }}$ dan $\mathrm{Z}_{\text {corr }}$ ) pada penelitian Paski dan Putra (2018) untuk mendapatkan koordinat terkoreksi (Lat* dan Lon ${ }^{\star}$ ) sesuai Persamaan (3) dan (4).

Lat ${ }^{*}=\operatorname{atan}\left(\frac{\frac{y \text { corr }}{\sqrt{x_{\text {Eorr }}+Z_{\text {Eorr }}}}}{R^{2}}\right) \frac{180}{\pi}$

$\operatorname{Lon}^{*}=\operatorname{atan} 2\left(x_{\text {corr }}+z_{\text {corr }}\right) \frac{180}{\pi}$

Penulis menggunakan kriteria MCS dalam penelitian Nuryanto dkk. (2019), yaitu brightness temparature terkoreksi $\left(\mathrm{BT}^{\star}\right) \leq 221$ derajat kelvin $(\mathrm{K})$, luasan $\mathrm{BT}^{\star} \geq 10.000 \mathrm{~km}^{2}$ dan durasi $\geq 3$ jam. Untuk mendapatkan $\mathrm{BT}^{\star}$ pada keempat lokasi tersebut, penulis menggunakan metode bilinear interpolation (Kim dkk., 2020) dan me-regridding $\mathrm{BT}^{\star}$ dari resolusi $4 \mathrm{~km}$ menjadi $100 \mathrm{~km}$ dengan menggunakan box average (MetOffice dan NOAA, 2016) agar mendapatkan $\mathrm{BT}^{\star}$ dengan luasan $\geq 100 \mathrm{~km} \times 100 \mathrm{~km}$ atau $10.000 \mathrm{~km}^{2}$ sesuai dengan kriteria MCS dan menghilangkan $\mathrm{BT}^{*} \leq 221 \mathrm{~K}$ dengan luasan $<10.000 \mathrm{~km}^{2}$ Durasi $\mathrm{BT}^{\star} \geq 3$ jam ditentukan dengan menganalisa life time klaster yang terbentuk. Penulis juga menggunakan data global land one-kilometer base elevation (GLOBE) digital elevation model (Hastings dan Paula, 1999) untuk mengeahui respon pergerakan MCS terhadap topografi karena pengaruh yang signifikan antara angin dan $\mathrm{CH}$ terhadap topografi di wilayah tropis (Riehl, 1954).

Dalam memahami proses dinamika atmosfer, penulis menganalisa pola pergerakan angin permukaan 10 m model reanalisis ECMWF generasi ke-5 (ERA5). Reanalisis ERA5 memiliki kualitas yang lebih baik dari reanalisis ERAInterim (Rivas dan Stoffelen, 2019). Selain itu, ERA5 juga memiliki resolusi temporal setiap jam dibandingkan resolusi ERA Interim yang hanya 6 jam. ERA5 juga mampu mensimulasikan konvergensi diurnal angin permukaan di Indonesia dibandingkan dengan model RegCM, MRCM dan
WRF, tetapi lebih cepat 2 jam (Rais dkk., 2019) sehingga angin permukaan diperlambat 2 jam (H-2) pada penelitian ini. Selain menganalisa arah dan kecepatan angin, penulis juga menganalisa divergensi. Divergensi menunjukan gerakan massa udara vertikal $(\Delta \mathrm{w} / \Delta \mathrm{z})$ dalam udara incompressible. Jika divergensi bernilai negatif maka akan terjadi pengumpulan massa udara dan berkaitan dengan pembentukan awan (Wirjohamidjojo dan Swarinoto, 2013). Semakin kecil nilai divergensi negatif, maka semakin besar awan yang terbentuk. Penulis menggunakan interval dan batasan maksimal divergensi $-2 \times 10^{-5} \mathrm{~s}^{-1}$ karena nilai tersebut mampu menunjukkan variasi divergensi di darat dan di laut (Rais dkk., 2019). Divergensi dihitung dari angin zonal dibagi resolusi bujur $(\Delta \mathrm{u} / \Delta \mathrm{x})$ dan angin angin meridional dibagi resolusi lintang $(\Delta \mathrm{v} / \Delta \mathrm{y})$ yang disajikan pada Persamaan (5)

$\frac{\Delta w}{\Delta z}=\frac{\Delta u}{\Delta x}+\frac{\Delta v}{\Delta y} \quad($ Stull, 2017)

Angin dan divergensi H-2 dibandingkan dengan klimatologinya periode 1979-2018 untuk mengetahui penyimpangan pola angin dan divergensi terhadap pola normalnya seperti dalam penelitian Siswanto dkk. (2017). Secara umum, diagram alir penelitian disajikan pada Gambar 2.

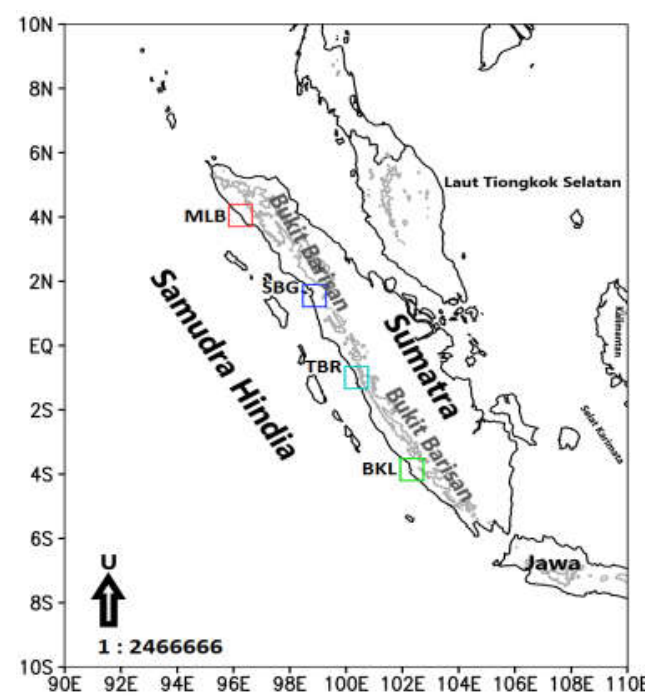

Gambar 1. Lokasi observasi CH.

(Sumber: pengolahan data, 2020)

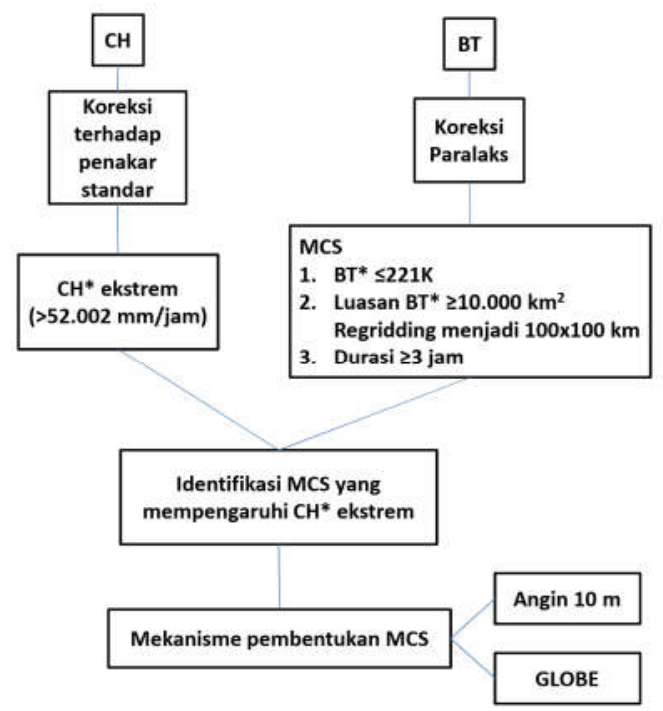

Gambar 2. Diagram alir penelitian 


\section{HASIL DAN PEMBAHASAN}

Koreksi CH dan BT

Pada Gambar 3a, $\mathrm{CH}$ setelah koreksi dengan Persamaan (2) umumnya menjadi lebih rendah dibandingkan $\mathrm{CH}$. $\mathrm{CH}^{\star}$ ekstrem di MLB, SBG, TBR dan BKL, secara berurutan, tetap $68 \mathrm{~mm} / \mathrm{jam}$, tetap $66 \mathrm{~mm} / \mathrm{jam}$, berubah dari $79 \mathrm{~mm} / \mathrm{jam}$ menjadi $70 \mathrm{~mm} / \mathrm{jam}$, serta berubah dari $58 \mathrm{~mm} /$ jam menjadi $55 \mathrm{~mm} / \mathrm{jam}$. Hal tersebut menandakan bahwa penakar Hellman bersifat overobserve, tetapi $\mathrm{CH}^{\star}$ masih termasuk kategori $\mathrm{CH}$ ekstrem karena $\mathrm{CH}^{*}>52.002 \mathrm{~mm} /$ jam sebagai hasil dari perhitungan pada Persamaan (1). Sedangkan pada Gambar $3 \mathrm{~b}, \mathrm{BT}^{*}$ umumnya juga mengalami penurunan nilai dibandingkan BT setelah koreksi dengan Persamaan (3) dan (4) pada saat $\mathrm{CH}$ ekstrem. Penurunan nilai $\mathrm{BT}^{\star}$ tersebut memperbesar peluang keberadaan MCS di MLB, SBG, TBR dan BKL karena memenuhi salah satu kriteria MCS yaitu $\mathrm{BT}^{\star} \leq 221 \mathrm{~K}$. Durasi $\mathrm{BT}^{*} \leq 221 \mathrm{~K}$ di MLB, SBG, TBR dan BKL berubah dari 4 jam 20 menit, 4 jam 20 menit, 1 jam 20 menit dan 2 jam menjadi 6 jam 40 menit, 5 jam 30 menit, 1 jam 50 menit dan 2 jam 10 menit.

\section{Identifikasi MCS yang mempengaruhi $\mathrm{CH}^{\star}$ ekstrem}

Seperti yang ditampilkan Gambar 3, $\mathrm{CH}^{\star}$ ekstrem 68 $\mathrm{mm} /$ jam di MLB terjadi pada pukul $14 \mathrm{Z}$ dengan $\mathrm{BT}^{\star}$ berkisar antara $214-219 \mathrm{~K}$ yang masuk kriteria $\mathrm{MCS}\left(\mathrm{BT}^{\star} \leq 221 \mathrm{~K}\right)$. Di SBG, $\mathrm{CH}^{*}$ ekstrem $66 \mathrm{~mm} / \mathrm{jam}$ terjadi pada pukul $12 \mathrm{Z}$ dengan $\mathrm{BT}^{*}$ pada kisaran nilai antara $201 \mathrm{~K}$ sampai $205 \mathrm{~K}$. Pada pukul 14Z, $\mathrm{CH}^{\star}$ ekstrem $70 \mathrm{~mm} /$ jam terjadi di TBR. Saat $\mathrm{CH}^{*}$ ekstrem tersebut, $\mathrm{BT}^{\star}$ yang berkisar antara 191$199 \mathrm{~K}$ yang juga memenuhi kriteria $\leq 221 \mathrm{~K}$. Sedangkan di $\mathrm{BKL}, \mathrm{CH}^{\star}$ ekstrem berlangsung pada pukul $13 \mathrm{Z}$ dengan nilai $\mathrm{BT}^{\star} \leq 221 \mathrm{~K}$. Jika MCS hanya dianalisa dengan citra BT pada menit ke-60 dan tanpa koreksi paralaks, seperti pada penelitian Trismidianto (2018), Norman dan Trilaksono (2019) serta Septiadi dan Nugraha (2020), maka BT hanya bernilai $223 \mathrm{~K}$ saat $\mathrm{CH}^{*}$ ekstrem di MLB yang tidak memenuhi kriteria MCS.

Di Gambar 4a, MCS tampak berada di sekitar MLB pada pukul $14 \mathrm{Z}$ saat $\mathrm{CH}^{*}$ ekstrem $68 \mathrm{~mm} / \mathrm{jam}$. MCS tersebut berasal dari 4 klaster MCS (notasi 1-4) yang bergabung menjadi klaster MCS besar di Sumatra bagian utara tersebut, meskipun klaster ke-3 berpisah pada pukul $12 \mathrm{Z}$ dan bergerak ke utara. Penggabungan klaster MCS juga dikemukakan dalam penelitian Putri dkk. (2017). Durasi klaster 1 dan 2 adalah 7 jam serta klaster 3 dan 4 memiliki durasi 8 jam. MCS juga

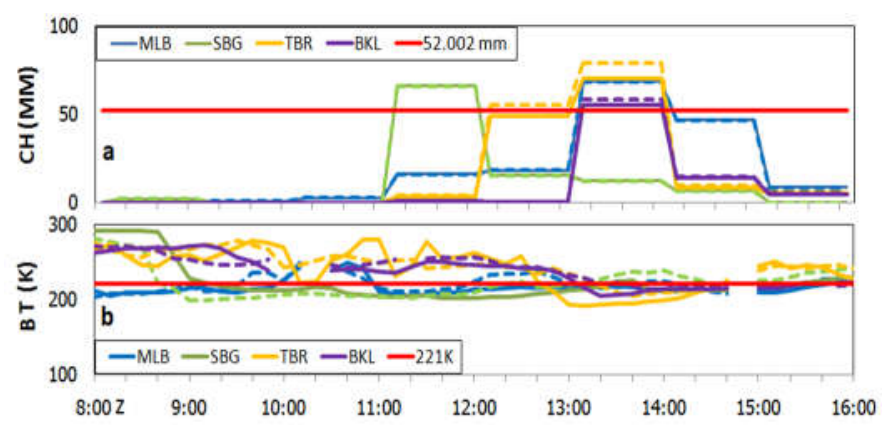

Gambar 3. (a) Grafik $\mathrm{CH}^{*}$ (garis penuh) serta $\mathrm{CH}$ (garis putus-putus) dan (b) grafik $\mathrm{BT}^{\star}$ (garis penuh) serta BT (garis putus-putus). Grafik hanya menampilkan data pada jam 8-16 coordinated universal time $(\mathrm{Z})$ karena hanya pada rentang waktu tersebut $\mathrm{CH}>0 \mathrm{~mm} / \mathrm{jam}$ (Sumber: pengolahan data, 2020). berada di SBG saat $\mathrm{CH}^{*}$ ekstrem $66 \mathrm{~mm} / \mathrm{jam}$ pukul $12 \mathrm{Z}$ yang berasal dari penggabungan 2 klaster MCS pada Gambar $4 \mathrm{~b}$. Adapun 2 klaster tersebut memiliki durasi 6 jam. Pada Gambar 4c, 2 klaster MCS dengan durasi 3 jam muncul pada pukul $13 Z$ yang terus berkembang dan bergabung hingga luasannya mencakup area TBR pada pukul $14 \mathrm{Z}$ saat $\mathrm{CH}^{\star}$ ekstrem 70 mm/jam. Begitu juga pada Gambar 4d, 2 klaster MCS berdurasi 8 jam berkembang dan bergabung hingga luasannya mencakup wilayah BKL saat $\mathrm{CH}^{*}$ ekstrem $55 \mathrm{~mm} /$ jam pukul 14Z. Semua durasi klaster MCS tersebut memenuhi kriteria minimal durasi MCS sebesar 3 jam.

\section{Mekanisme pembentukan MCS}

Secara klimatologi, Gambar 5a menunjukan bahwa angin permukaan $10 \mathrm{~m}$ berhembus dari perairan sebelah barat menuju MLB dan tidak menimbulkan divergensi $<-2 \times 10^{-5} \mathrm{~s}^{-1}$ yang dihitung dengan Persamaan (5) di MLB pada bulan Oktober pada pukul 12Z. Sedangkan klimatologi angin permukaan $10 \mathrm{Z}$ dan $12 \mathrm{Z}$ bulan Februari memperlihatkan bahwa terdapat divergensi $<-2 \times 10^{-5} \mathrm{~s}^{-1}$ terbentuk di perairan sebelah barat SBG dan TBR akibat interaksi angin permukaan yang berhembus dari Samudra Hindia dengan angin dari Bukit Barisan (Gambar 5b dan 5c). Di sekitar BKL, Gambar 5d menggambarkan bahwa terdapat divergensi $<-2 \times 10^{-5} \mathrm{~s}^{-1}$ akibat pertemuan angin pasat tenggara di Samudra Hindia sebelah selatan BKL dan angin dari barat di Samudra Hindia sebelah barat BKL. Semua pola klimatologi tersebut sesuai dengan penelitian Chang dkk. (2005) dan Qian (2008), yaitu angin baratan juga berhembus dari Samudra Hindia pada periode Desember-Februari serta angin pasat tenggara juga bertiup dari Samudra Hindia pada periode SeptemberNovember menuju pesisir barat Sumatra.

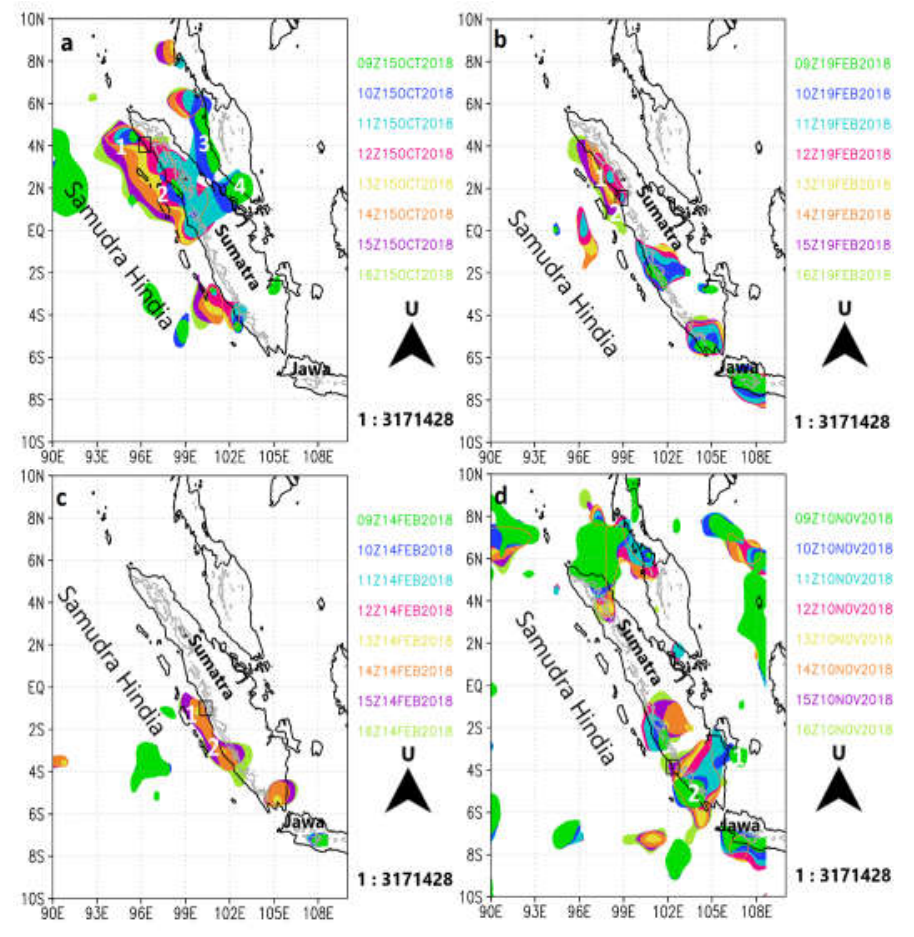

Gambar 4. Klaster maksimum MCS (angka warna putih) dengan resolusi grid $100 \mathrm{~km} \mathrm{x} 100 \mathrm{~km}$ (kriteria MCS) dalam 1 jam pada saat $\mathrm{CH}^{\star}$ ekstrem di sekitar lokasi (a) MLB, (b) SBG, (c) TBR, dan (d) BKL yag ditandai dengan kotak hitam. Bukit barisan ditandai dengan kontur abu-abu di Sumatra. Saat $\mathrm{CH}^{\star}$ ekstrem, MCS ditandai dengan kontur berwarna sesuai waktunya (Sumber: pengolahan data, 2020) 


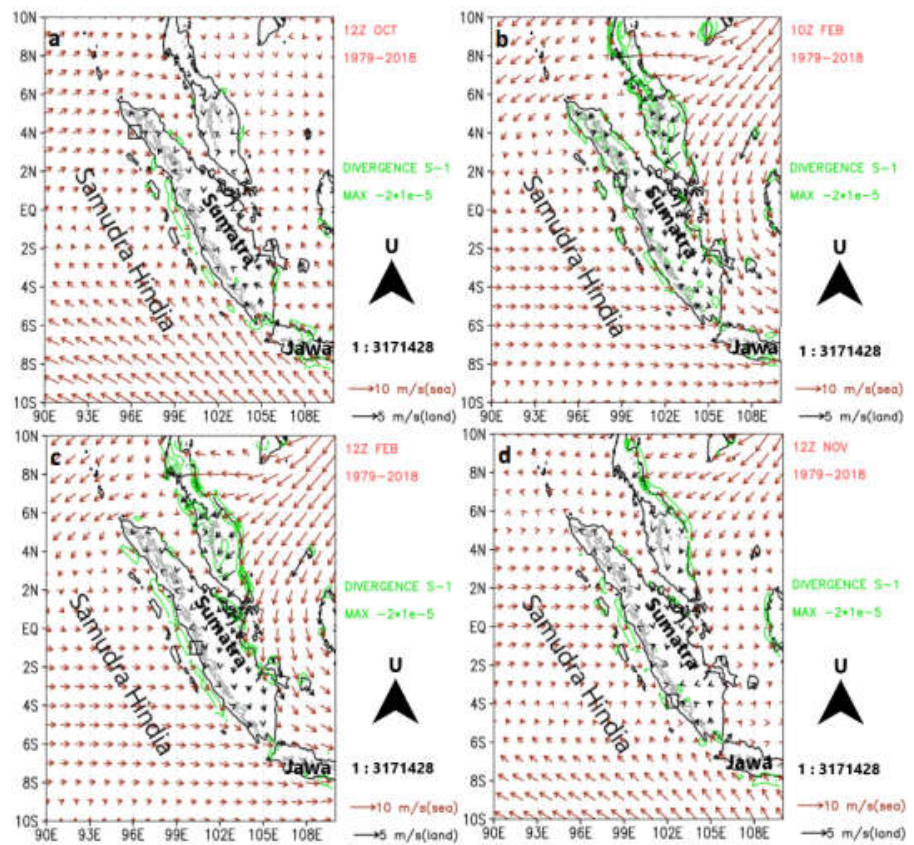

Gambar 5. Klimatologi angin dan divergensi periode 19792018 di lokasi (a) MLB, (b) SBG, (c) TBR, dan (d) BKL yang ditandai dengan kotak hitam. Bukit barisan ditandai dengan kontur abu-abu di Sumatra

(Sumber: pengolahan data, 2020)

Saat 2 jam sebelum $\mathrm{CH}^{\star}$ ekstrem (12Z) di MLB, angin dari Samudra Hindia sebelah barat daya MLB berhembus dengan kecepatan mencapai $10 \mathrm{~ms}^{-1}$ yang berinteraksi dengan angin dari bukit barisan bagian utara dan membentuk divergensi $<-6 \times 10^{-5} \mathrm{~s}^{-1}$ di sekitar MLB pada Gambar 6a. Divergensi negatif terbentuk dari angin pasat di Samudra Hindia sebelah barat daya Sumatra dan aliran siklonal (S) yang lemah di Samudra Hindia sebelah barat MLB. Aliran siklonik adalah aliran yang berotasi berlawanan arah dengan jarum jam untuk wilayah utara katulistiwa dan berkaitan dengan munculnya $\mathrm{CH}$ (Wirjohamidjojo dan Swarinoto, 2013). Sedangkan pada Gambar $6 b$ dan $6 c$, angin dari Samudra Hindia sebelah barat SBG dan TBR berhembus lebih kencang dari klimatologinya (Gambar 5b dan 5c), sehingga nilai divergensi mencapai $<-4 \times 10^{-5} \mathrm{~s}^{-1}$ yang lebih kecil dari klimatologinya. Melihat dari pola hembusannya, angin baratan yang berhembus tersebut kemungkinan berkaitan dengan westerly wind burst (WWB) yang dipengaruhi oleh intraseasonal variation (Seto dkk., 2006). Selain itu, MCS tampak tidak melewati Bukit Barisan (Gambar 4b dan 4c) karena aliran WWB terhalangi oleh Bukit Barisan (Nitta dkk., 1992).

Saat H-2 di BKL pada pukul 12Z, interaksi angin pasat tenggara di Samudra Hindia sebelah selatan BKL dengan angin dari barat di Samudra Hindia sebelah barat BKL membentuk divergensi negatif di sekitar BKL. Pola angin sama dengan klimatologinya, tetapi memiliki kecepatan yang lebih besar sehingga divergensi yang terbentuk jauh lebih kecil yang mencapai $<-4 \times 10^{-5} \mathrm{~s}^{-1}$ (Gambar $6 \mathrm{~d}$ ). Sama dengan pola angin pada kasus $\mathrm{CH}^{*}$ ekstrem di SBG dan TBR, WWB juga mungkin memberikan dampak terhadap pola aliran tersebut yang juga berinteraksi dengan angin pasat di Samudra Hindia sebelah barat daya BKL.
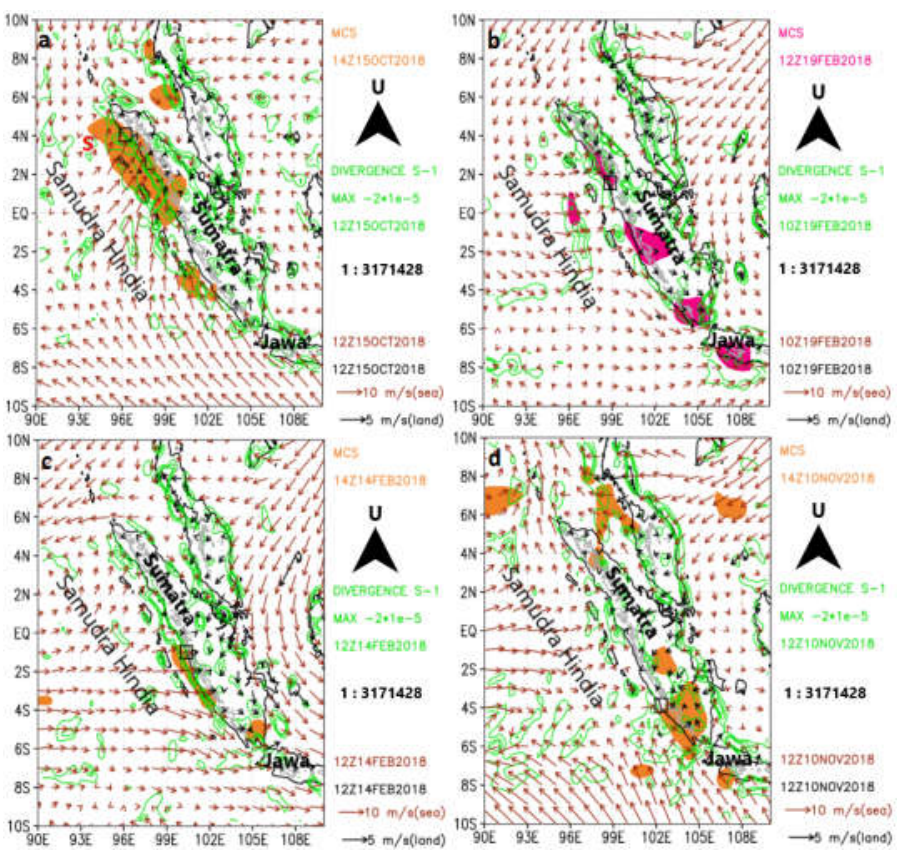

Gambar 6. Klaster maksimum MCS dalam 1 jam pada saat

$\mathrm{CH}^{*}$ ekstrem serta angin dan divergensi $\mathrm{H}-2$ di lokasi (a)

MLB, (b) SBG, (c) TBR dan (d) BKL yang ditandai dengan

kotak hitam. Bukit barisan ditandai dengan kontur abu-abu di Sumatra (Sumber: pengolahan data, 2020)

\section{KESIMPULAN}

Beberapa kasus MCS saat CH ekstrem pada tahun 2018 telah dibahas dalam penelitian ini menggunakan data IR rapidscan 10 menit, $\mathrm{CH}$ setiap jam, angin permukaan model reanalisis ERA5 dan GLOBE. Kriteria MCS yang digunakan adalah $\mathrm{BT}^{\star} \leq 221 \mathrm{~K}$, luasan $\mathrm{BT}^{\star} \geq 10.000 \mathrm{~km}^{2}$ dan durasi $\geq 3$ jam. Adapun kesimpulan yang didapatkan dari pembahasan di atas adalah bahwa MCS memiliki peran yang penting dalam pembentukan $\mathrm{CH}^{*}$ ekstrem di pesisir barat Sumatra. MCS tersebut sangat dipengaruhi oleh kemunculan WWB yang terhalangi oleh Bukit Barisan untuk kasus $\mathrm{CH}^{\star}$ ekstrem di SBG dan TBR atau berinteraksi dengan angin pasat tenggara dari Samudra Hindia sebelah barat daya Sumatra. Lain halnya saat $\mathrm{CH}^{\star}$ ekstrem di MLB, MCS terbentuk akibat interaksi angin pasat di Samudra Hindia sebelah barat Sumatra dan aliran siklonik sebelah barat MLB.

\section{UCAPAN TERIMA KASIH}

Penulis mengucapkan terima kasih kepada Pusat Meteorologi Penerbangan dan Pusat Penelitian dan Pengembangan BMKG yang telah memberikan dukungan dan kesempatan untuk melakukan penelitian ini. Kami juga mengucapkan terima kasih kepada para Reviewer dan Editor yang telah memberikan masukan dan arahan guna penyempurnaan tulisan ini.

\section{KONTRIBUSI PENULIS}

Penulis Pertama menyusun sistematika penelitian, mendesain metode penelitian, analisis data, dan membuat naskah publikasi; Penulis Kedua mendesain metode penelitian; dan Penulis Ketiga mendesain metode penelitian. 
DAFTAR PUSTAKA

BMKG. (2016). Pengamatan dan Pengelolaan Data Iklim di Lingkungan Badan Meteorologi Klimatologi dan Geofisika, PerKa No. 4 Thn. 2016.

BMKG. (2020). Pengamatan Harian. Diakses tanggal 2 Januari 2020 dari http://web.meteo.bmkg.go.id/id/pengamatan/ pengamatan-harian

Chang, C-P., Z. Wang, J. McBride, C-H Liu. (2005). Annual Cycle of Southeast Asia-Maritime Continent Rainfall and the Asymmetric Monsoon Transition. Journal of Climate.

Hastings, David A., dan Paula K. Dunbar, (1999). Global Land Onekilometer Base Elevation (GLOBE) Digital Elevation Model, Documentation, Volume 1.0. Key to Geophysical Records Documentation (KGRD) 34. National Oceanic and Atmospheric Administration, National Geophysical Data Center, 325 Broadway, Boulder, Colorado 80303, U.S.A.

Houze, R. A. (2018). 100 Years of Research on Mesoscale Convective Systems. Meteorological Monographs. DOI: 10.1175/ AMSMONOGRAPHS-D-18-0001.1

Ismanto H. (2011). Characteristics of Mesoscale Convective Complexes over Martitime Continent. (Tesis S2). Bandung : Sains Kebumian.

Kim, D., M-S Park, Y-J Park dan W. Kim. (2020). Geostationary Ocean Color Imager (GOCI) Marine Fog Detection in Combination with Himawari-8 Based on the Decision Tree Remote Sens. 2020, 12, 149; doi:10.3390/ rs12010149

MetOffice dan NOAA. (2016). Guidance on the Harmonized WAFS Grids for Cumulonimbus Cloud, Icing and Turbulence Forecasts Version 2.6

Mori, K. (2003). Hidrologi Untuk Pengairan. Jakarta : Pradya Paramita, 2003.

Mori, S., Jun-Ichi H, Tauhid Y I, Yamanaka M D, Okamoto N, Murata F, Sakurai N, Hashiguchi H dan Sribimawati T. (2004). Diurnal Land-Sea Rainfall Peak Migration over Sumatra Island, Indonesian Maritime Continent, Observed by TRMM Satellite and Intensive Rawinsonde Soundings. American Meteorology Society. 1322021 - 2039

Nitta, T., T. Mizuno dan K. Takahashi. (1992). Multi-Scale Convective Systems during the Initial Phase of the 1986/87 El Nino. J. Meteor. Soc. Japan, 70, pp 447-466.

Norman, Y., dan N. J. Trilaksono. (2019). Investigation of Mesoscale Convective Systems over Indonesian Maritime Continent using Geostationary Meteorological Satellite. IOP Conf. Series: Journal of Physics: Conf. Series 1204 (2019) 012124. doi:10.1088/1742-6596/1204/1/012124.

Nuryanto, D. E., Hidayat, P., Rahmat H., dan Edvin A. (2019). Characteristics of Two Mesoscale Convective Systems (MCSs) over the Greater Jakarta: Case of Heavy Rainfal Period 15-18 January 2013. Geosci. Lett. 6:1. doi:10.1186/ s40562-019-0131-5.

Paski, J. A. I. dan Richard, M. P. (2018). Pengaruh Koreksi Paralaks pada Data Satelit Himawari-08 Untuk Estimasi Curah $\mathrm{Hu}$ jan Ekstrim 20 September 2017 di Bengkulu. Dipresentasikan pada Seminar Nasional Penginderaan Jauh ke-5 Tahun 2018.

Putri, N. S., T. Hayasaka dan K. D. Whiteall. (2017). The Properties of Mesoscale Convective Systems in Indonesia Detected Using the Grab 'Em Tag 'Em Graph 'Em (GTG) Algorithm. Journal of the Meteorological Society of Japan, Vol. 95, No. 6, pp. 391-409. DOI:10.2151/jmsj.2017-026

Qian, J-H. (2008). Why Precipitation Is Mostly Concentrated over Islands in the Maritime Continent. Journal of Atm. Science. DOI : 10.1175/2007JAS2422.1.

Rais, A. F dan R. Yunita. (2017). Main diurnal cycle pattern of rainfall in East Java. AIP Conference Proceedings 1867, 020057. doi: 10.1063/1.4994460.

Rais, A. F., Soenardi, Z. Fanani dan P. Surgiansyah. (2019). Performa Konvergensi Angin Permukaan Diurnal Model Reanalisis ERA5 di Benua Maritim Indonesia. Jurnal Sains \&
Teknologi Modifikasi Cuaca, Vol.20 No.2, 2019 : 59 - 65. DOI: $10.29122 /$ jstmc.v20i2.3795

Riehl, H. (1954). Tropical Meteorology. McGraw-Hill, 392 pp.

Rivas, M. B. dan A. Stoffelen. (2019). Characterizing ERA-Interim and ERA5 surface wind biases using ASCAT. Ocean Sci., 15, 831-852. DOI : 10.5194/os-15-831-2019.

Septiadi, D. dan Y. Nugraha. (2020). Identifikasi Mesoscale Convective Complex (MCC) dan Dampaknya Terhadap Curah $\mathrm{Hu}-$ jan di Benua Maritim Indonesia (BMI) Sepanjang Tahun 2018. Jurnal Meteorologi dan Geofisika. Vol. 20 No. 2. DOI : 10.31172/jmg.v20i2.645.

Seto, T. H., M. K. Yamamoto, H. Hashiguchi, S. Fukao, M. Abo., T. Kozu., M. Kudsy. (2006). Observational Study on Westerly Wind Burst over Sumatra, Indonesia by the Equatorial Atmosphere Radar - A Case Study During the First CPEA Campaign, J. Meteor. Soc. Japan, 84A, pp 95-112

Siswanto, G. V. D. Schrier, G J V Oldenborghc, B V D Hurk, E. Aldrian, Y. Swarinoto, W. Sulistya dan A. E. Sakya. (2017). A very unusual precipitation event associated with the 2015 floods in Jakarta: an analysis of the meteorological factors. Weather and Climate Extremes 16 23-28. DOI : 10.1016/ j.wace.2017.03.003.

Stull, R. (2017). Practical Meteorology: An Algebra-based Survey of Atmospheric Version 1.02b. ISBN-13: 978-0-88865-283-6

Supriyadi, S., R Hidayati, R Hidayat dan A Sopaheluwakan. (2017). Mapping Extreme Rain Conditions in Sumatra by Influence Global Conditions. IOP Conf. Series: Earth and Environmental Science 58 012041. doi:10.1088/17551315/58/1/012041.

Trismidianto, Yulihastin, E., Satyawardhana, H., Nugroho, J.T., Ishida, S. (2017). The Contribution of the mesoscale convective complexes (MCCs) to total rainfall over Indonesian Maritime Continent. IOP Conf Ser: Earth. Environ. Sci. 54: 012027, DOI : 10.1088/17551315/54/1/012027.

Trismidianto. (2018). The Global Population of Mesoscale Convective Complexes (MCCs) over Indonesian Maritime Continent during 15 Years. IOP Conf. Series: Earth and Environmental Science 166 (2018) 012040. DOI :10.1088/17551315/166/1/012040

Wirjohamidjojo, S. dan Y. Swarinoto. (2013). Meteorologi Sinoptik Analisis dan Penaksiran Hasil Analisis Cuaca Sinoptik. ISBN : 978-602-1282-01-4. 